ORIGINAL ARTICLE

\title{
Return to school after brain injury
}

\author{
C A Hawley, A B Ward, A R Magnay, W Mychalkiw
}

Arch Dis Child 2004;89:136-142. doi: 10.1136/adc.2002.025577

\begin{abstract}
See end of article for authors' affiliations .....................

Correspondence to: C Hawley, Principal Research Fellow, Centre for Health Services Studies, University of Warwick, Coventry, CV4 7AL, UK. c.a.hawley@warwick. ac.uk
\end{abstract}

Accepted 4 June 2003

\begin{abstract}
Aims: To examine return to school and classroom performance following traumatic brain injury (TBI). Methods: This cross-sectional study set in the community comprised a group of 67 school-age children with TBI (35 mild, 13 moderate, 19 severe) and 14 uninjured matched controls. Parents and children were interviewed and children assessed at a mean of 2 years post injury. Teachers reported on academic performance and educational needs. The main measures used were classroom performance, the Children's Memory Scale (CMS), the Wechsler Intelligence Scale for Children-third edition UK (WISC-III) and the Weschler Objective Reading Dimensions (WORD).

Results: One third of teachers were unaware of the TBI. On return to school, special arrangements were made for 18 children (27\%). Special educational needs were identified for 16 (24\%), but only six children (9\%) received specialist help. Two thirds of children with TBI had difficulties with school work, half had attention/concentration problems and $26(39 \%)$ had memory problems. Compared to other pupils in the class, one third of children with TBI were performing below average. On the CMS, one third of the severe group were impaired/borderline for immediate and delayed recall of verbal material, and over one quarter were impaired/borderline for general memory. Children in the severe group had a mean full-scale $I Q$ significantly lower than controls. Half the $T B I$ group had a reading age $\geqslant 1$ year below their chronological age, one third were reading $\geqslant 2$ years below their chronological age.

Conclusions: Schools rely on parents to inform them about a TBI, and rarely receive information on possible long-term sequelae. At hospital discharge, health professionals should provide schools with information about TBI and possible long-term impairments, so that children returning to school receive appropriate support.
\end{abstract}

Timas raumatic brain injury (TBI) is relatively common among children and adolescents. ${ }^{1-3}$ Most injuries are mild; however, in the UK, every year approximately 3000 children acquire significant new neurological or cognitive disability as a result of $\mathrm{TBI}^{4}$ the sequelae of which may remain constant or deteriorate. ${ }^{5}$ Many children return to school after TBI without support or rehabilitation. ${ }^{6}$

It was previously assumed that children made good recoveries after brain injury because of the functional plasticity of the young brain. ${ }^{78}$ Current research suggests that as the brain continues to develop until adulthood, the young brain is particularly vulnerable to the effects of TBI. ${ }^{9}{ }^{10}$ Brain injury in childhood can lead to persistent cognitive and neurobehavioural deficits, and intellectual, academic and personality adjustment problems. ${ }^{11-16}$

Regardless of injury severity, children with TBI may have difficulties in retaining and retrieving newly learned information, ${ }^{17}{ }^{18}$ and for children with severe TBI, memory deficits may worsened over time. ${ }^{19}$ Memory and concentration impairments are particularly handicapping in the classroom..$^{20-23}$ Nevertheless, few researchers have investigated the effects these impairments may have on learning and educational performance.

The current study investigated issues surrounding return to school after brain injury. The aims were to:

- Examine the support provided by schools for children returning after TBI.

- Assess educational and intellectual performance and school difficulties after TBI.

\section{METHODS}

Participants

The study group was identified utilising a register of all children with brain injury aged $5-15$ years admitted to North
Staffordshire Hospital NHS Trust. Parents of 139 children with TBI completed a postal questionnaire and consented to be interviewed. All children with moderate or severe TBI were recruited. The mild group was recruited to match the moderate and severe groups for age, sex, and time since injury, resulting in 97 interviewees, of whom 82 were attending school at the time of the interviews and consented to their teachers being contacted by the research team.

Severity of TBI was determined using Glasgow Coma Scale $(\mathrm{GCS})^{24}$ scores and/or duration of loss of consciousness. Using the British Society of Rehabilitation Medicine classification of severity $^{25}$ (table 1), 21 (25.6\%) of the 82 children in the school group had severe TBI, 16 (19.5\%) moderate TBI, and 45 (54.9\%) mild TBI.

\section{Interviews}

Interviews and assessments took place in 1998/1999. Children and their families were interviewed at home by trained interviewers using a semistructured questionnaire. Areas covered were behaviour, emotion, cognition, physical problems, sensory deficits, mobility, school work, and school problems. Parents were asked about the support their child had been offered on return to school.

Abbreviations: CMS, Children's Memory Scale; FD, Freedom from Distractibility; FSIQ, Full Scale Intellectual Quotient; GCS, Glasgow Coma Scale; KOSCHI, King's Outcome Scale for Childhood Head Injury; NICE, National Institute for Clinical Excellence; PIQ, Performance IQ; PO, Perceptual Organisation; PS, Processing Speed; SENs, special educational needs; TBI, traumatic brain injury; VC, Verbal

Comprehension; VIQ, Verbal IQ; WISC-III, Wechsler Intelligence Scale for Children-third edition UK; WORD, Wechsler Objective Reading Dimensions 


\begin{tabular}{|ll|}
\hline $\begin{array}{l}\text { Table } 1 \\
\text { Severity of traumatic brain } \\
\text { injury }\end{array}$ & Definition \\
\hline Mild & $\begin{array}{l}\text { An injury causing unconsciousness for } \\
\text { less than } 15 \text { min and a GCS after initial } \\
\text { resuscitation of } 13-15 \\
\text { An injury causing unconsciousness for } \\
\text { more than } 15 \text { min but less than } 6 \mathrm{~h} \text { and } \\
\text { a GCS after initial resuscitation of } 9-12 \\
\text { An injury causing unconsciousness for } \\
\text { more than } 6 \mathrm{~h} \text { and a GCS after initial } \\
\text { resuscitation of } 3-8\end{array}$ \\
Severe & \\
\hline
\end{tabular}

\section{Control group}

Families with a child with brain injury identified a child of the same age, sex and social background and in the same school class as the injured child to act as a control. Thirty-one control children agreed to participate; none had a history of head injury or neurological impairment. All control families were interviewed, 20 children were still attending school and consented to their teachers being contacted by the research team.

\section{Teacher questionnaires}

Questionnaires were sent to head teachers with a request to pass it to the teacher who knew the child best. Nonresponders were telephoned and reminded. Of the 82 questionnaires posted, $67(81.7 \%)$ were completed and returned. Response rates were highest for children with severe TBI $(90.5 \%, 19$ teachers) and lowest for those with mild TBI (77.8\%, 35 teachers). Questionnaires were sent to head teachers for 20 control children; 14 (70\%) were completed and returned.

The questionnaire explored teachers' knowledge of the TBI, the child's educational performance, and special educational needs before and after the TBI. Teachers were asked to rate the pupil with TBI against the ability of his/her classroom peers. These questions were prefixed with: "Compared with other pupils in the class, how would you describe this child's ability in the following areas?" Abilities were then rated as "good", "average", "below average", or "poor".

\section{Ethical approval}

This study was approved by the Local Research Ethics Committee. Informed, written consent to participate was obtained from the parent, and for children aged $\geqslant 13$ years of age from the child him/herself.

\section{Measures}

The King's Outcome Scale for Childhood Head Injury (KOSCHI) was used to measure clinical outcomes. ${ }^{26}$ KOSCHI scores were derived from interviews with parents and children and scored by one team member $(\mathrm{CH})$ with experience of the KOSCHI. The KOSCHI contains five categories: 1, death; 2, vegetative; 3 , severe disability; 4, moderate disability; 5 , good recovery (subdivided into 5A, some residual deficits not affecting daily living, and 5B, full recovery with no identified sequelae).

All psychological assessments were carried out by trained psychology assistants under the supervision of a consultant clinical neuropsychologist. The Wechsler Intelligence Scale for Children-third edition UK (WISC-III) ${ }^{27}$ was used to assess intelligence. Seven index scores were computed: Full Scale Intellectual Quotient (FSIQ), Verbal IQ (VIQ), Performance IQ (PIQ), Verbal Comprehension (VC), Perceptual Organisation (PO), Freedom from Distractibility (FD), and Processing Speed (PS). The Wechsler Objective Reading Dimensions (WORD) ${ }^{28}$ were used to compare reading age with chronological age.

\section{Memory and attention}

The Children's Memory Scale (CMS) ${ }^{29}$ was used to assess learning and memory. The CMS has standardized scores where an index score of 100 reflects average performance.

Table 2 Characteristics of the school study group

\begin{tabular}{|c|c|c|c|c|}
\hline Variable & $\begin{array}{l}\text { Mild } \\
(n=35)\end{array}$ & $\begin{array}{l}\text { Moderate } \\
(n=13)\end{array}$ & $\begin{array}{l}\text { Severe } \\
(n=19)\end{array}$ & $\begin{array}{l}\text { Control } \\
(n=14)\end{array}$ \\
\hline Gender: number male (\%) & $21(60 \%)$ & $11(84.6 \%)$ & $8(42.1 \%)$ & $6(42.9 \%)$ \\
\hline \multicolumn{5}{|l|}{ Mechanism of injury } \\
\hline Fall (\%) & $16(45.7 \%)$ & $3(23.1 \%)$ & $2(10.6 \%)$ & - \\
\hline RTA pedestrian (\%) & $6(17.1 \%)$ & $4(30.8 \%)$ & $13(68.4 \%)$ & - \\
\hline RTA in vehicle (\%) & $0(0 \%)$ & $1(7.7 \%)$ & $3(15.8 \%)$ & - \\
\hline RTA cyclist (\%) & $3(8.6 \%)$ & 0 & $1(5.3 \%)$ & - \\
\hline All RTAs & $9(25.7 \%)$ & $5(38.5 \%)$ & $17(89.5 \%)$ & - \\
\hline Fall from bicycle (\%) & $7(20 \%)$ & $2(15.4 \%)$ & 0 & - \\
\hline Assault (\%) & $1(2.9 \%)$ & $1(7.7 \%)$ & 0 & - \\
\hline Sport (\%) & 0 & $1(7.7 \%)$ & 0 & - \\
\hline Collision with another child (\%) & $2(5.7 \%)$ & 0 & 0 & - \\
\hline Kicked by horse (\%) & 0 & $1(7.7 \%)$ & 0 & - \\
\hline Total & 35 (100\%) & $13(100 \%)$ & $19(100 \%)$ & - \\
\hline \multicolumn{5}{|l|}{ Age at injury (yr) } \\
\hline Mean (SD) & $8.89(2.99)$ & $8.31(2.98)$ & $9.79(2.35)$ & - \\
\hline Range & $5-14$ & $5-15$ & $6-14$ & - \\
\hline \multicolumn{5}{|l|}{ Age at interview (yr) } \\
\hline Mean (SD) & $11.69(2.89)$ & $11.85(3.34)$ & $12.79(2.49)$ & $11.93(2.79)$ \\
\hline Range & $6-18$ & $7-16$ & $8-17$ & $7-16$ \\
\hline \multicolumn{5}{|c|}{ Years between injury and follow-up } \\
\hline Mean (SD) & $2.03(1.47)$ & $2.85(1.77)$ & $1.95(1.39)$ & NA \\
\hline Range & $0-5$ & $0-6$ & $0-5$ & \\
\hline \multicolumn{5}{|l|}{ Days off school affer TBI } \\
\hline Mean(SD) & $21.7(29.7)$ & $23.2(17.9)$ & $135.9(148.4)$ & NA \\
\hline Range & $0-112$ & $7-62$ & $30-450$ & \\
\hline Therapeutic input for TBI (\%) & $4(11.4 \%)$ & $1(7.7 \%)$ & $4(21 \%)$ & - \\
\hline \multicolumn{5}{|l|}{ Townsend social deprivation } \\
\hline Mean (SD) & $+1.13(2.53)$ & $-0.21(3.64$ & $+1.49(2.71)$ & $-0.64(2.5)$ \\
\hline
\end{tabular}




\begin{tabular}{|c|c|c|c|c|}
\hline Variable & $\begin{array}{l}\text { Mild } \\
(n=35)\end{array}$ & $\begin{array}{l}\text { Moderate } \\
(n=13)\end{array}$ & $\begin{array}{l}\text { Severe } \\
(n=19)\end{array}$ & $\begin{array}{l}\text { Significance } \\
(\mathrm{df}=2)\end{array}$ \\
\hline Key teacher aware of TBI & $21(60 \%)$ & $9(69.2 \%)$ & $16(84.2 \%)$ & \multirow{6}{*}{$\begin{array}{l}p=0.19 \\
\chi^{2}=3.36 \\
p=0.02 \\
\chi^{2}=7.51 \\
p=0.17 \\
\chi^{2}=3.54 \\
p=0.0001 \\
\chi^{2}=17.2 \\
p=0.14 \\
\chi^{2}=3.93 \\
p=0.06 \\
\chi^{2}=5.64\end{array}$} \\
\hline $\begin{array}{l}\text { All teachers who teach the child are } \\
\text { aware of } T B I\end{array}$ & $14(40 \%)$ & $7(53.8 \%)$ & $15(78.9 \%)$ & \\
\hline $\begin{array}{l}\text { Special arrangements on return to } \\
\text { school }\end{array}$ & $6(17.1 \%)$ & $5(38.5 \%)$ & $7(36.8 \%)$ & \\
\hline Staggered return to school & 0 & $2(15.4 \%)$ & $8(42.1 \%)$ & \\
\hline $\begin{array}{l}\text { Special educational needs identified } \\
\text { prior to TBI }\end{array}$ & $3(8.6 \%)$ & 0 & $4(21.1 \%$ & \\
\hline $\begin{array}{l}\text { Current special educational needs } \\
\text { identified }\end{array}$ & $7(20 \%)$ & $1(7.7 \%)$ & $8(42.1 \%)$ & \\
\hline
\end{tabular}

The scale provides a global measure (General Memory Index) and seven further index scores: Attention/Concentration; Verbal and Visual Immediate Memory; Verbal and Visual Delayed Memory; Delayed Recognition; Learning.

\section{Social deprivation}

The Townsend Deprivation Index ${ }^{30}$ was used to measure social deprivation. The higher the positive score the more deprived an area, the higher the negative score the more prosperous an area. For the UK, the mean is zero, for North Staffordshire the mean is -0.49 .

\section{Statistical analyses}

Analyses were performed on data for children with completed teacher questionnaires, 67 in the TBI group and 14 in the control group, all using SPSS Version 9.0.

\section{RESULTS}

\section{Study group characteristics (table 2)}

Time spent absent from school after the TBI varied widely. Some injuries took place during school holidays, so not all children missed school. In the mild group, two children also had orthopaedic injuries and were absent for several months.

\section{Clinical recovery}

Most children had made a moderate or good recovery as measured by the KOSCHI. Only one child, with severe TBI, had severe disability, and two thirds (46) had moderate disability (24 mild, eight moderate, 14 severe). Twenty $(29.9 \%)$ made a good recovery (11 mild, five moderate, four severe); of these, one child with mild TBI made a full recovery with no discernible sequelae. There were no significant differences between severity groups.

\section{Teachers' knowledge of TBI}

The majority of parents $(55,82.1 \%)$ said that their child's teachers knew about the TBI. Five parents said that the primary school had known, but when their child changed schools teachers were unaware of the TBI. Teachers reported that for 21 children $(31 \%)$ no one informed the school about the TBI. The school was informed by parents ( 34 children, $50.7 \%$ ); the child him/herself (four children, 6\%); "other agencies" (eight children, 12\%), and by a hospital (one child, $1.5 \%)$.

\section{Special arrangements on return to school}

Eighteen parents (26.9\%) reported that schools made special arrangements for their child's return after the TBI. There was a significant difference between severity groups $(p=0.001$, $\left.\chi^{2}=18.79, \mathrm{df}=2\right)$. Special arrangements were made for $63.2 \%$ (12) of the severe, $23.1 \%$ (three) of the moderate and $8.6 \%$ (three) of the mild group, usually for physical limitations, for example being excused physical exercise and/or being kept indoors at breaks ( 11 children), or being watched by teachers (nine children).

Teachers' reports of arrangements are shown in table 3.

\section{Special educational needs}

Twenty parents $(29.9 \%)$ reported that schools provided extra educational assistance when their child first returned after the TBI. No differences were observed between severity groups. Teachers reported that 16 children in the TBI group $(23.9 \%)$ were currently on the school's special educational needs (SENs) register, seven of whom $(43.8 \%)$ were on the register prior to the TBI. The Department for Education's Code of Practice recommends a staged approach to meeting children's special educational needs:

- Stage 1 -concerns are recorded and discussed between parents and teachers.

- Stage 2-an individual education plan is written by teachers.

- Stage 3-the school is likely to seek specialist advice from external professionals.

- Stages 4 and 5-additional resources should be provided to meet the child's needs.

Of the 16 children on a SENs register, there were four at Stage 1, six at Stage 2, one at Stage 3, two at Stage 4, and

Table 4 Intellectual functioning and special educational needs

\begin{tabular}{lllll}
\hline & $\begin{array}{l}\text { SENs identified } \\
(\mathbf{n}=16)\end{array}$ & $\begin{array}{l}\text { No SENs identified } \\
(\mathbf{n}=\mathbf{5 4})\end{array}$ & Significance & $\mathbf{9 5 \%} \mathbf{C l}$ \\
\hline FSIQ mean (SE) & $79.56(2.4)$ & $96.0(2.2)$ & 0.0001 & 9.8 to 23.0 \\
VIQ mean (SE) & $81.5(3.2)$ & $95.96(2.3)$ & 0.002 & 5.5 to 23.5 \\
PIQ mean (SE) & $82.25(2.4)$ & $96.44(2.2)$ & 0.0001 & 7.6 to 20.8 \\
\hline
\end{tabular}


Table 5 Child's difficulties as reported by parents

\begin{tabular}{llllll}
\hline Difficulties & $\begin{array}{l}\text { Mild } \\
(\mathbf{n}=35)\end{array}$ & $\begin{array}{l}\text { Moderate } \\
(\mathbf{n}=13)\end{array}$ & $\begin{array}{l}\text { Severe } \\
(\mathbf{n}=19)\end{array}$ & $\begin{array}{l}\text { Control } \\
(\mathbf{n}=13)\end{array}$ & Significance \\
\hline Memory & $14(40 \%)$ & $4(30.8 \%)$ & $8(42.1 \%)$ & $1(7.7 \%)$ & NS \\
Attention/concentration & $20(57.1 \%)$ & $8(61.5 \%)$ & $14(73.7 \%)$ & $4(30.8 \%)$ & NS \\
Learning new information & $15(42.9 \%)$ & $4(30.8 \%)$ & $10(52.6 \%)$ & $2(15.4 \%)$ & NS \\
School work & $23(65.7 \%)$ & $7(53.8 \%)$ & $14(73.7 \%)$ & $3(23.1 \%)$ & $p=0.024, \chi^{2}=9.4$ \\
\hline NS, not significant. & & & &
\end{tabular}

three at Stage 5. Therefore, 10 children $(62.5 \%)$ were at the preliminary assessment stages and unlikely to be receiving specialist help. According to parents, the assistance currently provided ranged from daily support to monthly support from a SENs teacher. There was a significant relationship between the provision of SENs and IQ (table 4).

\section{Parental reports of school difficulties}

Parents identified the main difficulties for their children as memory, attention/concentration, learning new information, and school work (table 5).

\section{Teacher questionnaires}

Teachers reported that approximately half the children in the mild and moderate groups had problems with school work, memory, and attention (table 6). There was a significant relationship between memory problems and difficulties with school work $\left(p=0.0001, \chi^{2}=43.6, d f=1\right), 94.4 \%$ of children with memory problems also had some difficulties with school work.

Table 7 shows the number of pupils with poor or below average classroom performance. Approximately 40\% of children with TBI, of any severity, performed below the class average on their ability to focus attention and filter out distractions. There was no association between social deprivation and school performance $(\mathrm{p}=0.23)$.

\section{Intellectual ability}

The WISC-III assessed general intelligence for 54 children with TBI and 14 controls (table 8). Significant differences were observed between controls and the severe group for FSIQ ( $p=0.027$, CI 1.7 to 25.1 ), PS ( $p=0.005$, CI 6.0 to 29.4), and VC ( $\mathrm{p}=0.047$, CI 0.2 to 22.7); between the mild and severe groups for PS ( $p=0.013$, CI 3.0 to 24.1); and between the mild and control groups for VIQ ( $\mathrm{p}=0.05$, CI 0.1 to 21.8), and VC ( $\mathrm{p}=0.045$, CI 0.3 to 22.7$)$.

Children living in areas with positive Townsend scores (more deprived) had a significantly lower IQ than those living in areas with negative scores (more prosperous). Differences were found for FSIQ $(p=0.02$, CI -18.5 to $-1.6)$ and VIQ $(p=0.03, \mathrm{CI}-18.5$ to -1.2$)$, but not for PIQ $(p=0.07$, CI -16.0 to 0.6$)$.

\section{Childrens' memory scale (CMS)}

Fifty-three children with TBI were assessed using the CMS (table 9). Approximately one third of children with severe TBI were impaired or borderline for immediate and delayed recall of verbal material, and over one quarter were impaired or borderline for both general memory and recall of visually presented material.

Teachers' ratings for each child were compared with scores on the CMS. For most items, children rated as "good" by teachers achieved average or above average scores on the CMS. Significant associations were observed between teacher ratings of attention in class and the CMS Attention/ Concentration Index scores for "ability to maintain attention" $\left(p=0.014, \chi^{2}=29.52, d f=15\right)$, and "ability to shift attention" $\left(p=0.03, \chi^{2}=19.96, d f=10\right)$.

\section{Reading ability}

Thirty-six pupils with TBI were assessed for reading ability on the WORD. Overall, there was a mean discrepancy between chronological age and reading age of -0.5 years $(\mathrm{SD}=2.63)$. Nineteen pupils $(52.8 \%)$ were reading at a level $\geqslant 1$ year below their chronological age and $13(36.1 \%)$ at a level $\geqslant 2$ years below. No significant differences were observed between the three severity groups. For the severe group, there was a mean discrepancy between chronological and actual reading age of -1.7 years.

For all measures, there were no significant differences between children assessed $>1$ year post injury and those assessed $\leqslant 1$ year post injury.

\section{DISCUSSION}

Almost one third of teachers were unaware that the child had suffered a TBI. The most usual source of information about

Table 6 Responses to teacher questionnaires

\begin{tabular}{lcllll}
\hline Variable & $\begin{array}{l}\text { Mild } \\
(\mathbf{n}=33)\end{array}$ & $\begin{array}{l}\text { Moderate } \\
(\mathbf{n = 1 3 )}\end{array}$ & $\begin{array}{l}\text { Severe } \\
(\mathbf{n = 1 9 )}\end{array}$ & $\begin{array}{l}\text { Control } \\
(\mathbf{n}=14)\end{array}$ & $\begin{array}{l}\text { Significance } \\
(\mathbf{d f}=6)\end{array}$ \\
\hline $\begin{array}{l}\text { Visual difficulties } \\
\text { Hearing difficulties }\end{array}$ & $1(3 \%)$ & 0 & $2(10.5 \%)$ & $1(7.1 \%)$ & $p=0.49, \chi^{2}=2.41$ \\
Mobility difficulties & $1(3 \%)$ & 0 & 0 & 0 & $p=0.72, \chi^{2}=1.33$ \\
Difficulties with school work & $18(54.5 \%)$ & $6(46.2 \%)$ & $15(78.9 \%)$ & $4(28.6 \%)$ & $p=0.003, \chi^{2}=13.73$ \\
$\begin{array}{l}\text { Doesn't pay attention or } \\
\text { listen }\end{array}$ & $15(45.5 \%)$ & $8(61.5 \%)$ & $12(63.2 \%)$ & $5(35.7 \%)$ & $p=0.33, \chi^{2}=3.73$ \\
Memory problems & $16(48.5 \%)$ & $6(46.2 \%)$ & $14(73.7 \%)$ & $1(7.1 \%)$ & $p=0.001, \chi^{2}=21.64$ \\
Has mood swings & $9(27.3 \%)$ & $7(53.8 \%)$ & $11(57.9 \%)$ & $2(14.3 \%)$ & $p=0.002, \chi^{2}=20.38$ \\
Lacks confidence & $17(51.5 \%)$ & $8(61.5 \%)$ & $13(68.4 \%)$ & $6(42.9 \%)$ & $p=0.13, \chi^{2}=13.74$ \\
Fatigue & $12(36.4 \%)$ & $8(61.5 \%)$ & $12(63.2 \%)$ & $3(21.4 \%)$ & $p=0.08, \chi^{2}=11.10$ \\
Problems making self & $9(27.3 \%)$ & $2(15.4 \%)$ & $6(31.6 \%)$ & $3(21.4 \%)$ & $p=0.13, \chi^{2}=13.76$ \\
understood & $10(30.3 \%)$ & $7(53.8 \%)$ & $9(47.4 \%)$ & $4(28.6 \%)$ & $p=0.65, \chi^{2}=4.2$ \\
$\begin{array}{l}\text { Socially inappropriate } \\
\text { behaviours }\end{array}$ & & & & & \\
\hline
\end{tabular}




\begin{tabular}{|c|c|c|c|c|c|}
\hline Ability & $\begin{array}{l}\text { Mild } \\
(n=33)\end{array}$ & $\begin{array}{l}\text { Moderate } \\
(n=13)\end{array}$ & $\begin{array}{l}\text { Severe } \\
(n=19)\end{array}$ & $\begin{array}{l}\text { Control } \\
(n=14)\end{array}$ & Significance \\
\hline Ability to focus attention & $15(45.5 \%)$ & $5(38.5 \%)$ & $7(38.9 \%)$ & $2(14.3 \%)$ & $p=0.42, \gamma^{2}=6.01$ \\
\hline Ability to maintain attention & $12(36.4 \%)$ & $3(23.1 \%)$ & $7(38.9 \%)$ & $3(21.4 \%)$ & $p=0.39, \chi^{2}=6.28$ \\
\hline Ability to shift attention & $9(27.3 \%)$ & 0 & $5(26.3 \%)$ & $1(7.1 \%)$ & $p=0.27, \chi^{2}=7.64$ \\
\hline $\begin{array}{l}\text { Ability to divide attention } \\
\text { between topics }\end{array}$ & $11(33.3 \%)$ & $2(15.4 \%)$ & $4(21.1 \%)$ & $3(21.4 \%)$ & $p=0.72, \chi^{2}=3.67$ \\
\hline $\begin{array}{l}\text { Ability to analyse a task into } \\
\text { component parts }\end{array}$ & $10(30.3 \%)$ & $1(7.7 \%)$ & $6(31.6 \%)$ & $3(21.4 \%)$ & $p=0.48, \chi^{2}=5.53$ \\
\hline $\begin{array}{l}\text { Ability to grasp the main concept } \\
\text { from detailed information }\end{array}$ & $9(27.3 \%)$ & $1(7.7 \%)$ & $8(42.1 \%)$ & $4(28.6 \%)$ & $p=0.11, \chi^{2}=10.74$ \\
\hline $\begin{array}{l}\text { Ability to consider a variety of } \\
\text { solutions }\end{array}$ & 11 (33.3\%) & $1(7.7 \%)$ & $6(31.6 \%)$ & $2(14.3 \%)$ & $p=0.25, \chi^{2}=7.88$ \\
\hline Ability to plan activities & $11(33.3 \%)$ & $1(7.7 \%)$ & $5(26.3 \%)$ & $2(14.3 \%)$ & $p=0.04, \chi^{2}=13.04$ \\
\hline $\begin{array}{l}\text { Ability to initiate behaviour (ie } \\
\text { start a task without help) }\end{array}$ & $14(42.4 \%)$ & $2(15.4 \%)$ & $6(31.6 \%)$ & $3(21.4 \%)$ & $p=0.36, \chi^{2}=6.61$ \\
\hline $\begin{array}{l}\text { Ability to respond to others to } \\
\text { ensure that behaviour is always } \\
\text { socially appropriate }\end{array}$ & $8(24.2 \%)$ & $3(23.1 \%)$ & $5(26.3 \%)$ & 0 & $p=0.53, \chi^{2}=5.09$ \\
\hline
\end{tabular}

the injury came from parents; the discharging hospital informed the school for only one child. Parents reported a lack of communication about the brain injury between one school and another, for example when a child progressed from primary to secondary school. The majority of children in our sample had made a good physical and motor recovery with no obvious visible signs of a brain injury. Teachers are rarely conversant with possible long-term effects of TBI, and many commented that as the TBI had occurred some years ago, they did not consider the child's current school performance to be related to the injury. Consequently, even when teachers did know about the TBI, allowances were not routinely made for the possible effects of that injury. Other investigators have made similar observations, and concluded that there is inadequate educational provision for children after brain injury, largely due to inaccurate or poor information for schools, poor communication between schools and hospitals, and inadequate training of teaching staff into the effects of TBI. ${ }^{31}{ }^{32}$ This situation may improve in the future, as the 2002 National Institute for Clinical Excellence (NICE) guidelines recommend that schools should receive information from hospitals for all children who receive a CT scan following TBI. ${ }^{33}$

Only nine children had received any form of rehabilitation following the TBI, most were discharged home without assessment, support, or advice about return to school, findings consistent with those of others. ${ }^{34}$ It is, therefore, unsurprising that special arrangements were provided for so few children on their return to school, and only 10 had a staggered return to school. Even when special arrangements were made, schools tended to focus upon physical disability rather than cognitive impairments.
A strong relationship was observed between intellectual functioning and the provision of special educational needs (SENs), indicating that children with a low IQ are most likely to receive additional educational support. However, those who perform adequately, but according to their parents not as well as previously, tend to be overlooked. Recent research suggests that even when SENs are identified following a brain injury, those needs are only actually provided for in two thirds of cases. ${ }^{6}$ In the current study, of the 16 children with TBI who were on the school's register of SENs, two thirds $(11,68.8 \%)$ were at Stages $1-3$, and therefore had not received a statutory assessment of SENs by the local education authority. As such, they were unlikely to be receiving specialist help to meet their needs.

Seven children were identified as having SENs prior to their TBI, and were slow learners before the injury. However, the association between premorbid intellectual functioning and TBI is unclear. ${ }^{35-37}$

Of those pupils assessed using the WORD, over half the children with TBI were reading at a level at least one year below their chronological age, and over one third were reading at a level two or more years below their chronological age. These findings are virtually identical to those reported by others. $^{38} 39$

This study found that children continue to exhibit impairments of memory and attention up to 5 years after TBI. Problems were most prevalent amongst children who had suffered a severe TBI. Similar findings have been observed by others. ${ }^{40}$ Acquisition of knowledge and skills may be impaired following TBI, and information learnt one day may be forgotten the next. ${ }^{41}$ Children with TBI may find it harder to concentrate, and become easily distracted. This

\begin{tabular}{lllll} 
Table 8 & Summary of intellectual performance & & \\
\hline WISC-III Index Scores & $\begin{array}{l}\text { Mild TBI } \\
(\mathbf{n}=\mathbf{3 1})\end{array}$ & $\begin{array}{l}\text { Moderate TBI } \\
(\mathbf{n}=11)\end{array}$ & $\begin{array}{l}\text { Severe TBI } \\
(\mathbf{n}=14)\end{array}$ & $\begin{array}{l}\text { Controls } \\
(\mathbf{n}=14)\end{array}$ \\
\hline FSIQ mean (SE) & $90.07(3.2)$ & $93.82(4.5)$ & $86.57(3.9)$ & $99.93(4.1)$ \\
VIQ mean (SE) & $89.26(3.1)$ & $97.09(5.4)$ & $89.14(3.7)$ & $100.21(4.3)$ \\
PIQ mean (SE) & $94.39(4.1)$ & $91.36(2.9)$ & $87.21(4.1)$ & $98.0(4.8)$ \\
VC mean (SE) & $88.84(3.2)$ & $96.91(5.4)$ & $88.93(3.4)$ & $100.36(4.3)$ \\
PO mean (SE) & $92.45(3.2)$ & $91.09(2.7)$ & $86.21(3.9)$ & $97.71(4.6)$ \\
PS mean (SE) & $99.74(2.8)$ & $94.64(3.9)$ & $86.21(4.8)$ & $103.93(3.1)$ \\
FD mean (SE) & $94.94(2.6)$ & $100.82(4.4)$ & $97.86(4.1)$ & $104.79(4.9)$ \\
\hline
\end{tabular}

$\mathrm{SE}$, standard error of the mean. 
Table 9 Mean index scores on the Child's Memory Scale

\begin{tabular}{|c|c|c|c|c|}
\hline CMS item & $\begin{array}{l}\text { Mild } \\
(n=28)\end{array}$ & $\begin{array}{l}\text { Moderate } \\
(n=11)\end{array}$ & $\begin{array}{l}\text { Severe } \\
(n=14)\end{array}$ & $\begin{array}{l}\text { Difference between } \\
\text { groups }\end{array}$ \\
\hline $\begin{array}{l}\text { General Memory Index } \\
\text { mean (SD) }\end{array}$ & 98.25 (20.54) & $95.36(18.99)$ & $82.79(17.04)$ & $p=0.06, F=3.03$ \\
\hline $\begin{array}{l}\text { Aftention/Concentration } \\
\text { Index mean (SD) }\end{array}$ & $97.39(14.09)$ & 105.64 (13.71) & $95.43(23.70)$ & $p=0.40, F=0.93$ \\
\hline $\begin{array}{l}\text { Verbal Immediate Index } \\
\text { mean (SD) }\end{array}$ & $101.5(18.89)$ & $92.91(19.05)$ & $85.86(22.48)$ & $p=0.06, F=3.0$ \\
\hline $\begin{array}{l}\text { Verbal Delayed Index mean } \\
\text { (SD) }\end{array}$ & 100.5 (14.65) & 97.82 (18.57) & 83.36 (19.35) & $p=0.04, F=3.51$ \\
\hline $\begin{array}{l}\text { Visual Immediate Index mean } \\
\text { (SD) }\end{array}$ & $97.29(16.09)$ & $93.73(18.87)$ & $84.93(14.70)$ & $p=0.17, F=1.83$ \\
\hline $\begin{array}{l}\text { Visual Delayed Index mean } \\
\text { (SD) }\end{array}$ & $97.93(12.98)$ & $95.82(17.71)$ & 86.29 (13.47) & $p=0.05, F=3.22$ \\
\hline $\begin{array}{l}\text { Delayed Recognition Index } \\
\text { mean (SD) }\end{array}$ & 97.46 (18.34) & $103.18(19.46)$ & 94.93 (13.36) & $p=0.49, F=0.72$ \\
\hline Learning Index mean (SD) & $99.86(17.76)$ & $86.36(17.49)$ & $86.36(19.81)$ & $p=0.08, F=2.73$ \\
\hline
\end{tabular}

can be a major problem in the school situation, and they may need extra input from teachers and additional supervision to keep them focused and on-task. This does not routinely happen.

\section{CONCLUSIONS}

When a child is discharged from hospital after TBI, their school should be provided with information on the injury, and the possible long-term cognitive and behavioural deficits which may arise. Schools should then "tag" the records of children who have sustained a TBI that was serious enough for hospital admission, and information be made available to all teachers who teach the child. This information should be transferred between schools to avoid these children getting "lost" in the system.

\section{Authors' affiliations}

C A Hawley, Centre for Health Services Studies, University of Warwick, Coventry, UK

A B Ward, North Staffordshire Rehabilitation Centre, Stoke-on-Trent, Staffordshire, UK

A R Magnay, Paediatric Intensive Care Unit, City General Hospital, Stoke-on-Trent

W Mychalkiw, Department of Psychology, City General Hospital, Stoke-on-Trent

\section{REFERENCES}

1 Kraus JF, Rock A, Hemyari P. Brain injuries among infants, children, adolescents, and young adults. Am J Dis Child 1990;144:684-91.

2 Guyer B, Ellers B. Childhood injuries in the United States. Am J Dis Child 1990;144:649-52.

3 Snow JH, Hooper SR. Pediatric traumatic brain injury. California: Sage, 1994.

4 Sharples PM. Head injury in children. In: Ward Platt MP, Little RA, eds. Injury in the young. Cambridge: Cambridge University Press, 1998:151-75.

5 Taylor HG, Alden J. Age-related differences in outcomes following childhood brain insults: an introduction and overview. J Int Neuropsychol Soc 1997;3:555-67.

6 Hawley CA, Ward AB, Magnay A, et al. Children's brain injury: a postal follow-up of 525 children from one health region in the UK. Brain Injury 2002;16:969-85.

7 Kennard MA. Age and other factors in motor recovery from precentral lesions in monkeys. Am J Physiol 1936;115:138-46.

8 Kennard MA. Relation of age to motor impairment in man and subhuman primates. Arch Neurol Psychiatry 1940;44:377-97.

9 Dennis $M$, Wilkinson $M$, Koski L, et al. Attention deficits in the long term after childhood head injury. In: Bronan SH, Michel ME, eds. Traumatic head injury in children. New York: Oxford University Press, 1995:165-87.

10 Slomine BS, Gerring JP, Grados MA, et al. Performance on measures of "executive function" following pediatric traumatic brain injury. Brain Injury 2002; 16:759-72.

11 Ewing-Cobbs L, Miner ME, Fletcher JM, et al. Intellectual, motor, and language sequelae following closed head injury in infants and preschoolers. J Pediatr Psychol 1989;14:531-7.
12 Klonoff H, Clark C, Klonoff PS. Long-term outcome of head injuries: a 23 year follow up study of children with head injuries. J Neurol Neurosurg Psychiatry 1993;56:410-15.

13 Ewing-Cobbs L, Thompson NM, Miner ME, et al. Gunshot wounds to the brain in children and adolescents: age and neurobehavioural development. Neurosurgery 1994;35:225-33.

14 Parmelee DX. Neuropsychiatric sequelae of traumatic brain injury in children and adolescents. Psychiatr Med 1989;7:11-16.

15 Levin HS, Benton AL, Grossman RG. Neurobehavioural consequences of closed head injury. New York: Oxford University Press, 1982.

16 Levin HS, Eisenberg HM, Wigg NR, et al. Memory and intellectual ability after head injury in children and adolescents. Neurosurgery 1982;11:668-73.

17 Levin HS, Eisenberg HM. Neuropsychological outcome of closed head injury in children and adolescents. Child's Brain 1979;5:281-92.

18 Donders J. Memory functioning after traumatic brain injury in children. Brain Injury 1993;7:431-7.

19 Anderson VA, Morse SA, Klug G, et al. Predicting recovery from head injury in young children: a prospective analysis. J Int Neuropsychol Soc 1997;3:568-80.

20 Catroppa C, Anderson V. Recovery in memory function in the first year following TBI in children. Brain Injury 2002;16:369-84.

21 Bevington J, Wishart JG. The influence of classroom peers on cognitive performance in children with behavioural problems. Br J Educ Psychol 1999;69:19-32.

22 Martin RP, Gaddis L, Drew D, et al. Prediction of elementary school achievement from preschool temperament: three studies. School Psychol Rev 1988; 17:125-37.

23 Martin RP, Nagle R, Paget K. Relationships between temperament and classroom behaviour, teacher attitudes and academic achievement. J Clin Psychol 1983;39:1013-20.

24 Teasdale G, Jennett B. Assessment of coma and impaired consciousness: a practical scale. Lancet 1974;ii:81-3.

25 British Society of Rehabilitation Medicine. Rehabilitation after traumatic brain injury. A Working Party Report of the British Society of Rehabilitation Medicine. London, 1998.

26 Crouchman $M$, Rossiter $L$, Colaco $T$, et al. A practical outcome scale for paediatric head injury. Arch Dis Child 2001;84:120-4.

27 Wechsler D. Manual for the Wechsler Intelligence Scale for Children-third edition UK, WISC-III(UK). Sidcup: The Psychological Corporation, 1991.

28 Wechsler D. Weschler Objective Reading Dimensions. London: The Psychological Corporation, 1993.

29 Cohen B. Children's Memory Scale. San Antonio: The Psychological Corporation, 1997.

30 Townsend P, Phillimore P, Beattie A. Inequalities in health in the Northern Region. Newcastle upon Tyne: Northern Regional Health Authority and University of Bristol, 1986.

31 Jones A, Johnson D. A study of the educational provision for head-injured children. Br J Spec Educ 1994;21:113-17.

32 Johnson DA, Munro S, Pentland B, et al. Educational needs after head injury in children. Report to the Scottish Office. Edinburgh: Astley Ainslie Hospital, 1998.

33 National Institute for Clinical Excellence. Head injury in infants, children and adults: triage, assessment, investigation and early management (NICE guideline). Second consultation draft, December 2002.

34 Scott-Jupp R, Marlow N, Seddon N, et al. Rehabilitation and outcome after severe head injury. Arch Dis Child 1992;67:222-6.

35 Oddy M. Head injury during childhood. Neuropsychol Rehabil 1993:3:301-20.

36 Chadwick O, Rutter M, Shaffer D. A prospective study of children with head injuries: IV, specific cognitive deficits. J Clin Neuropsychol 1981;3:101-20.

37 Klonoff $\mathrm{H}$. Head injury in children: predisposing factors. Am J Public Health 1971;61:2404-17. 
38 Shaffer $\mathrm{D}, \mathrm{Bijur} P$, Chadwick $\mathrm{O}$, et al. Head injury and later reading disability. J Am Acad Child Psychiatry 1980;19:592-610.

39 Donders J, Warschausky S. WISC-III factor index score patterns after traumatic head injury in children. Child Neuropsychol 1997;3:71-8.
40 Nelson JE, Kelly TP. Long-term outcome of learning and memory in children following severe closed head injury. Pediatr Rehabil 2002;5:37-41.

41 Middleton JA. Practitioner review: psychological sequelae of head injury in children and adolescents. J Child Psychol Psychiatry 2001;42:165-80.

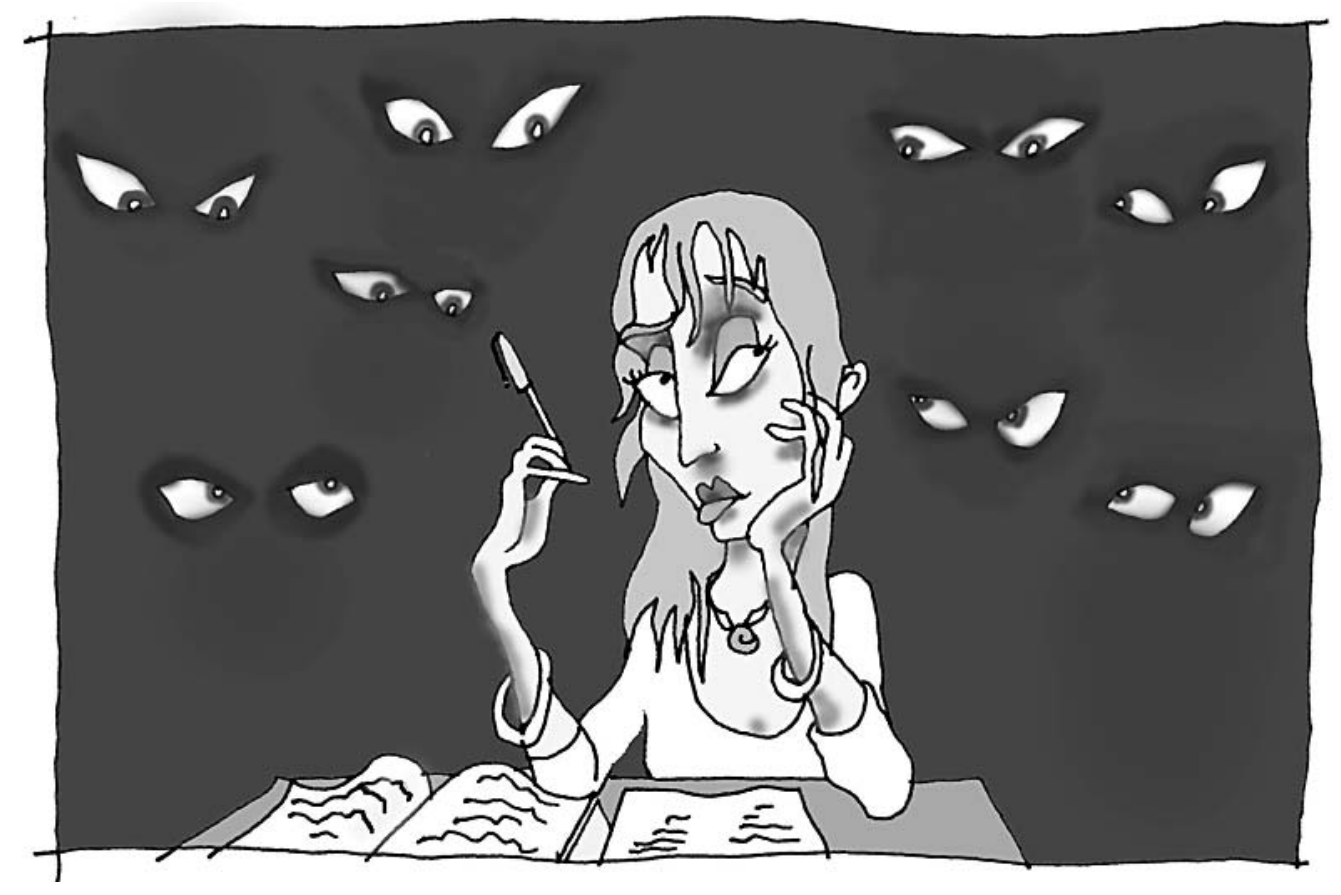

